\title{
CHEMOTAXIS OF NEUTROPHIL LEUCOCYTES TOWARDS SPERMATOZOA AND SEMINAL FLUID*
}

\author{
E. S. MARONI, $\uparrow$ D. N. K. SYMON AND P. G. WILKINSON \\ Department of Bacteriology and Immunology, \\ University of Glasgow, Scotland
}

(Received 9th March 1971, accepted 3rd May 1971)

\begin{abstract}
Summary. The chemotactic activity for neutrophil leucocytes of the isolated spermatozoa and of the sperm-free seminal fluid was studied by a modification of Boyden's technique. Both spermatozoa and seminal fluid were found to attract neutrophils in the presence of serum or plasma, but not in their absence. The activity of seminal fluid is probably mediated in part by the complement system but it is unlikely that the classical haemolytic complement reaction is responsible for the activity of spermatozoa.
\end{abstract}

\section{INTRODUGTION}

The fate of those spermatozoa in the female reproductive tract which do not fertilize the ovum has been the subject of many studies. Phagocytosis of spermatozoa by polymorphonuclear leucocytes and occasionally by mononuclear cells has been reported in the mouse and rat (Austin, 1957), golden hamster (Yanagimachi \& Chang, 1963), rabbit (Menge, Tyler \& Casida, 1962), cattle (Howe \& Black, 1963) and in man (Moyer, Rimdusit \& Mishell, 1970), and it probably represents an important mechanism for the removal of spermatozoa.

Mobilization of leucocytes from the wall into the lumen of the reproductive tract precedes phagocytosis of the spermatozoa. Thus, in several species a striking migration of polymorphonuclear leucocytes into the lumen of the vagina and uterus is observed shortly after copulation or insemination (Hartman, 1928; Austin, 1957; Pitkjanen, 1960; Yanagimachi \& Chang, 1963). Various explanations have been proposed for this migration of polymorphonuclear leucocytes; for example, distension of the uterus with fluid after copulation (Austin, 1957), bacteria introduced into the uterus (McDonald, Black, McNutt \& Casida, 1952), a direct effect of semen itself (Howe \& Black, 1963, postulated that, since the addition of antibiotics followed by negative bacterial cultures still elicited migration, this response could not have been mediated by bacteria) and the release of a leucotactic substance by spermatozoa in the uterus (Menge et al., 1962). Of these possibilities, the last seemed to us the most likely.

* Departmental Publication No. 7104.

† Present address: Universitaets-Frauenklinik, Zürich, Switzerland. 
This paper describes the results of experiments designed to test the possibility that spermatozoa or seminal fluid are chemotactically attractive to phagocytic cells. In contrast to the observations of leucocyte migration towards the deposited semen in vivo, no studies in vitro with a system that allows quantitative measurement of chemotaxis have yet been published. The technique introduced by Boyden (1962) seemed to be ideally suited to measure the chemotactic activity for leucocytes of spermatozoa and seminal fluid after incubation in various media.

Two classes of chemotactic agent have been recognized (Keller \& Sorkin, 1967a, 1968). These have been named (a) cytotaxins, which act directly to cause cell migration, and (b) cytotaxigens, which have no direct chemotactic activity but which, when placed in biological fluids such as serum or plasma, activate substances which initiate chemotaxis. The complement system is known to be of considerable importance as such an initiator, the split products of complement such as C3a (Bokisch, Müller-Eberhard \& Cochrane, 1969) and C5a (Snyderman, Shin, Phillips, Gewurz \& Mergenhagen, 1969) being highly chemotactic, but there are probably other non-complement-dependent initiators (Sorkin, Stecher \& Borel, 1970). The activity of spermatozoa and of seminal fluid as both cytotaxins and cytotaxigens was examined in this study.

\section{MATERIALS AND METHODS}

Gey's solution

This was prepared as described by Paul (1959) and penicillin $(200 \mathrm{U} / \mathrm{ml})$ and streptomycin $(50 \mu \mathrm{g} / \mathrm{ml})$ were added. This medium was used as the diluent in all experiments.

\section{Spermatozoa}

Living spermatozoa from normal human donors, attending an Infertility Clinic but with normal sperm counts and normal sperm motility and morphology, were used. Epididymal spermatozoa from normal guinea-pigs were also used in certain experiments to examine the activity of spermatozoa obtained under bacteria-free conditions and uncoated with seminal fluid.

\section{Preparation of human spermatozoa}

Semen was obtained from several donors, brought to $4^{\circ} \mathrm{C}$ within $2 \mathrm{hr}$ of ejaculation and pooled. Gey's solution, containing streptomycin and penicillin, was then added. The spermatozoa were centrifuged at $2000 \mathrm{rev} / \mathrm{min}$ for $10 \mathrm{~min}$ at $4^{\circ} \mathrm{C}$ and were washed three times in Gey's solution. They were then made up to a concentration of $40 \times 10^{6}$ spermatozoa in $4 \mathrm{ml}$ diluent.

\section{Preparation of guinea-pig spermatozoa}

The vasa deferentia and epididymides of freshly killed guinea-pigs were dissected and carefully cleaned from the surrounding fat and blood vessels. Gey's solution was forced through the vas deferens and the epididymis was slit when the pressure had distended its tubules. The epididymal spermatozoa were collected in a Petri dish, distributed in test tubes, washed three times in the 
same way as the human spermatozoa and made up to a concentration of $40 \times 10^{6} / 4 \mathrm{ml}$ suspension.

\section{Human seminal fuid}

Human sperm-free seminal fluid was obtained from vasoligated men. It was prepared within $2 \mathrm{hr}$ after ejaculation by spinning for $20 \mathrm{~min}$ at $3000 \mathrm{rev} / \mathrm{min}$ at $4^{\circ} \mathrm{C}$, and the supernatant was removed and stored at $-20^{\circ} \mathrm{C}$ till needed. The pooled specimens consisted of seminal fluid from up to eight donors.

\section{Serum and plasma}

Guinea-pig plasma was obtained from heparinized blood withdrawn from normal healthy guinea-pigs by heart puncture, and stored at $-70^{\circ} \mathrm{C}$ until required. Guinea-pig serum was obtained by allowing blood obtained from normal healthy guinea-pigs to clot, and was stored at $-70^{\circ} \mathrm{C}$ until required. Serum preserved by the method of Richardson (1941) was also used in some tests (Complement VD10, Burroughs Wellcome, Beckenham, Kent). The serum or plasma was inactivated, when appropriate, by heating at $56^{\circ} \mathrm{C}$ for $30 \mathrm{~min}$.

\section{Preparation of test solutions}

Various combinations of spermatozoa or seminal fluid in Gey's solution with or without fresh and heat-inactivated plasma were prepared.

The following combinations were tested: (a) spermatozoa $\left(40 \times 10^{6}\right.$ cells) in $4 \mathrm{ml}$ Gey's solution; (b) spermatozoa $\left(40 \times 10^{6}\right.$ cells $)+0.4 \mathrm{ml}$ of either serum or plasma (fresh or inactivated) made up to $4 \mathrm{ml}$ in Gey's solution; (c) spermfree seminal fluid $(1 \mathrm{ml}$ ) made up to $4 \mathrm{ml}$ in Gey's solution; (d) sperm-free seminal fluid $(1 \mathrm{ml})+0.4 \mathrm{ml}$ of either serum or plasma (fresh or inactivated) and made up to $4 \mathrm{ml}$ in Gey's solution; (e) spermatozoa $\left(40 \times 10^{6}\right.$ cells) + bovine fibrin (10 mg) (B.D.H. Ltd) in $4 \mathrm{ml}$ Gey's solution; (f) sperm-free seminal fluid $(1 \mathrm{ml})+$ fibrin $(10 \mathrm{mg})$ made up to $4 \mathrm{ml}$ in Gey's solution.

All mixtures were incubated at $37^{\circ} \mathrm{C}$ for $30 \mathrm{~min}$ and then heat-inactivated at $56^{\circ} \mathrm{G}$ for $30 \mathrm{~min}$ before use in chemotaxis tests. All spermatozoa were invariably killed by this heat treatment.

Appropriate controls were set up as indicated in Tables 1, 2 and 3.

\section{Chemotaxis}

Chemotaxis was measured in vitro using the chamber described by Wilkinson (1971). This is a simplified and smaller version of the chamber originally described by Boyden (1962). It is a chamber with two compartments, separated by a 'Millipore' filter membrane. Leucocytes present in the upper compartment will migrate through the filter membrane only when a chemotactic agent is placed in the lower compartment (Text-fig. 1). The lower compartment is a 5 -ml glass beaker which is filled with $4 \mathrm{ml}$ of the chemotactic substance under test. The upper compartment consists of the sawn-off barrel of a tuberculin syringe with a circular filter glued to the lower end. The cell suspension is placed in the upper compartment before immersion of the latter in the lower compartment. Three upper compartments are suspended in each lower 
TABLE 1

CHEMOTAGTIC AGTIVITY OF EJAGULATED HUMAN SPERMATOZOA FOR HUMAN NEUTROPHILS IN THE PRESENCE AND ABSENCE OF GUINEA-PIG PLASMA OR SERUM

\begin{tabular}{|c|c|c|}
\hline Test substance & \multicolumn{2}{|c|}{$\begin{array}{l}\text { Neutrophils/high power field } \\
\text { (Mean for three filters } \pm S . E .)\end{array}$} \\
\hline $\begin{array}{l}\text { CoNTRoLs } \\
\text { Gey's solution } \\
\text { Casein }(0 \cdot 5 \%) \text { in Gey's solution } \\
\text { Guinea-pig plasma }(10 \%) \text { in Gey's solution } \\
\text { Guinea-pig serum }(10 \%) \text { in Gey's solution }\end{array}$ & $\begin{array}{r}0 \\
307 \\
1 \\
6\end{array}$ & $\begin{array}{l} \pm 0 \\
\pm 21 \\
\pm 0 \\
\pm 1\end{array}$ \\
\hline $\begin{array}{l}\text { TEST* } \\
\text { 1. Human spermatozoa alone } \\
\text { 2. Human spermatozoa + guinea-pig plasma }(10 \%) \\
\text { preheated for } 30 \text { min at } 56^{\circ} \mathrm{C} \\
\text { 3. Human spermatozoa + fresh guinea-pig plasma } \\
\text { 4. Human spermatozoa + guinea-pig serum }(10 \%) \\
\text { preheated for } 30 \text { min at } 56^{\circ} \mathrm{C} \\
\text { 5. Human spermatozoa + fresh guinea-pig serum } \\
(10 \%)\end{array}$ & $\begin{array}{r}3 \\
2 \\
70 \\
143 \\
75\end{array}$ & $\begin{array}{l} \pm 0 \\
\pm 0 \\
\pm 4 \\
\pm 26 \\
\pm 6\end{array}$ \\
\hline
\end{tabular}

* In each test, spermatozoa were used at a concentration of $40 \times 10^{6} /$ chamber.

$P$-values for all experiments: Test $1:$ Test $2 ; 0.333$. Test $1:$ Test $3 ;<0.001$. Test 1 : Test $4 ; 0.009$. Test $1:$ Test $5 ; 0.015$. Test 2 : Test $3 ; 0.020$. Test 4 : Test $5 ; 0.046$.

compartment, permitting all experiments to be performed in triplicate. In addition, all experiments are repeated at least three times.

Neutrophils were obtained by dextran sedimentation of heparinized human blood from normal, healthy persons. The cells were washed three times in Gey's solution and suspended in the upper chamber in a volume of $0.2 \mathrm{ml}$ at a concentration of 4 to $8 \times 10^{6} / \mathrm{ml}$. The filter was a 3- $\mu \mathrm{m}$ cellulose ester filter (Millipore Filter Corp., Bedford, Mass.) as recommended by Keller \& Sorkin (1967b). The tests were incubated for $3 \mathrm{hr}$ at $37^{\circ} \mathrm{C}$ and the filters then fixed, detached

TABLE 2

CHEMOTACTIG AGTIVITY OF GUINEA-PIG EPIDIDYMAL SPERMATOZOA FOR HUMAN NEUTROPHILS IN THE PRESENCE AND ABSENGE OF GUINEA-PIG SERUM

\begin{tabular}{l|rc}
\hline \multicolumn{1}{c|}{ Test substance } & $\begin{array}{c}\text { Neutrophils/high power field } \\
\text { (Mean for three filters } \pm \text { S.E.) }\end{array}$ \\
\hline $\begin{array}{l}\text { CoNTRoLs } \\
\text { Gey's solution }\end{array}$ & 1 & \pm 1 \\
$\begin{array}{l}\text { Casein }(0 \cdot 5 \%) \text { in Gey's solution } \\
\text { Guinea-pig serum (10\%) in Gey's solution }\end{array}$ & 445 & \pm 102 \\
\hline $\begin{array}{l}\text { TEsT* } \\
\text { Guinea-pig epididymal spermatozoa }\end{array}$ & 1 & \pm 1 \\
$\begin{array}{l}\text { Guinea-pig epididymal spermatozoa + guinea-pig } \\
\text { serum (10\%) preheated for 30 min at } 56^{\circ} \mathrm{C}\end{array}$ & 136 & \pm 8 \\
$\begin{array}{l}\text { Guinea-pig epididymal spermatozoa + fresh guinea- } \\
\text { pig serum (10\%) }\end{array}$ & 33 & \pm 3 \\
\hline
\end{tabular}

* Guinea-pig epididymal spermatozoa were used at a concentration of $40 \times 10^{6} /$ chamber. 
from the syringe barrels, stained with haematoxylin and reversed onto a microscope slide. Neutrophil leucocytes adhering to the lower surface of the filter were counted giving a measure of the migration of cells through the filter. Four high power fields were counted on each filter and the mean count per field was calculated. All tests included a positive and a negative control. The negative control was Gey's solution which is not itself chemotactic. The positive control was a solution of crude casein (Merck AG, Darmstadt, Germany, 'Casein alkalilöslich') at $5 \mathrm{mg} / \mathrm{ml}$ in Gey's solution. Casein consistently attracted neutrophil leucocytes giving counts of several hundred cells per high power field on the lower surface of the filter.

\section{Complement fixation tests and complement titration}

Complement fixation tests were performed using standard haemolytic techniques. Complement was titrated in the presence and absence of spermatozoa using the technique described by Campbell, Garvey, Cremer \& Sussdorf (1964).

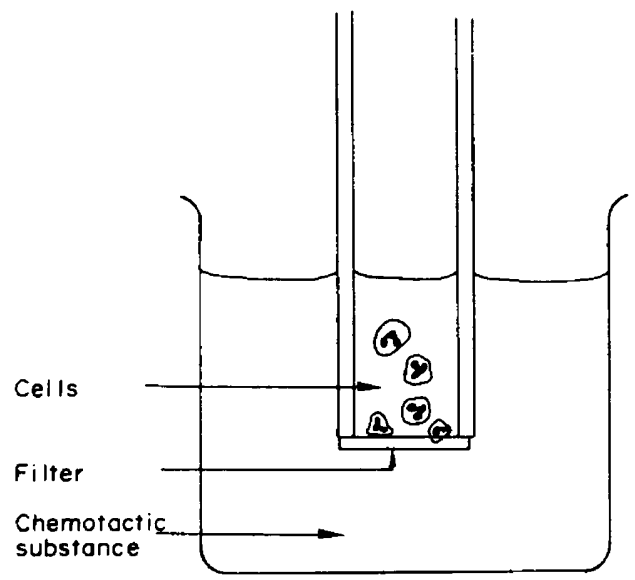

TEXT-FIG. 1. Diagram of the chemotactic chamber.

\section{RESULTS}

Chemotactic activity of spermatozoa for human neutrophil leucocytes

The results of representative experiments in Tables 1 and 2 show that ejaculated human spermatozoa and epididymal guinea-pig spermatozoa exert no chemotactic activity in the absence of serum or plasma. It is also apparent that on addition of fresh unheated guinea-pig serum or plasma to either human or guinea-pig spermatozoa, a chemotactic factor is generated. If plasma is heat-inactivated before being added to the test, this factor is not produced, but if serum is pre-inactivated, its chemotactic effect is usually somewhat greater than that of unheated serum (Pl. 1, Figs. 1 and 2).

Chemotactic activity of sperm-free seminal fluid from vasoligated men

Table 3 demonstrates that human seminal fluid alone shows a slight chemo- 
tactic attraction for neutrophils, and that the addition of fresh serum or plasma increases considerably the chemotactic activity of human seminal fluid. If the serum or plasma is first heat-inactivated before addition to the test, this chemotactic effect is reduced slightly but is not abolished. No difference was observed between serum and plasma in these tests.

This result differs from the classical effect seen with other cytotaxigens, e.g. bacterial endotoxin, which act by complement fixation. Endotoxin stimulates strong chemotactic activity in the presence of fresh serum, but no activity in the presence of heated serum (Snyderman, Gewurz \& Mergenhagen, 1968). If the seminal fluid itself is preheated to $56^{\circ} \mathrm{C}$ for $30 \mathrm{~min}$, it shows an identical chemotactic behaviour to that of unheated seminal fluid shown in Table 3.

TABLE 3

GHEMOTACTIC ACTIVITY OF HUMAN SPERM-FREE SEMINAL FLUID FOR HUMAN NEUTROPHILS IN THE PRESENGE AND ABSENCE OF GUINEA-PIG PLASMA OR SERUM

\begin{tabular}{|c|c|c|}
\hline Test substance & $\begin{array}{l}\text { Neutro } \\
(\text { Mean }\end{array}$ & $\begin{array}{l}\text { ower field } \\
\text { ers } \pm \text { S.E. }\end{array}$ \\
\hline $\begin{array}{l}\text { CoNTRoLs } \\
\text { Gey's solution } \\
\text { Gasein }(0.5 \%) \text { in Gey's solution } \\
\text { Guinea-pig plasma }(10 \%) \text { in Gey's solution } \\
\text { Guinea-pig serum }(10 \%) \text { in Gey's solution }\end{array}$ & $\begin{array}{r}1 \\
399 \\
2 \\
2\end{array}$ & $\begin{array}{l} \pm 1 \\
\pm \\
\pm 1 \\
\pm 1 \\
\pm\end{array}$ \\
\hline $\begin{array}{l}\text { TEST } \\
\text { 1. Human seminal fluid }(25 \%) \\
\text { 2. Human seminal fluid + guinea-pig plasma }(10 \%) \\
\text { preheated for } 30 \text { min at } 56^{\circ} \mathrm{C} \\
\text { 3. Human seminal fluid + fresh guinea-pig plasma } \\
(10 \%) \\
\text { 4. Human seminal fluid + guinea-pig serum }(10 \%) \\
\text { preheated for } 30 \text { min at } 56^{\circ} \mathrm{C} \\
\text { 5. Human seminal fluid + fresh guinea-pig serum } \\
(10 \%)\end{array}$ & $\begin{array}{r}11 \\
225 \\
345 \\
170 \\
270\end{array}$ & $\begin{array}{l} \pm 4 \\
\pm 64 \\
\pm 60 \\
\pm 6 \\
\pm 13\end{array}$ \\
\hline
\end{tabular}

$P$-values for all experiments : Test 1 : Test $2 ;<0.001$. Test 1 : Test $3 ;<0.001$. Test 1 : Test $4 ;<0.001$. Test $1:$ Test $5 ; 0.001$. Test 2 : Test $3 ; 0.067$. Test $4:$ Test $5 ; 0.091$.

Chemotactic activity of seminal fluid in the presence of fibrin

If seminal fluid is incubated in the presence of a preparation of crude bovine fibrin, moderate chemotactic activity is generated. Spermatozoa, however, show no chemotactic activity in the presence of fibrin.

\section{Complement-fxing activity of seminal fluid and spermatozoa}

Seminal fluid at a dilution of 1 in 2 or 1 in 4 fixes complement and inhibits lysis of sensitized erythrocytes in a conventional complement fixation test. At higher dilutions, this fixation is no longer seen. The action of spermatozoa on guinea-pig complement was studied by estimating the complement titre before and after incubation with spermatozoa. The haemolytic curve of samples of guinea-pig complement was not altered upon incubation with living or dead, human or guinea-pig, spermatozoa. 


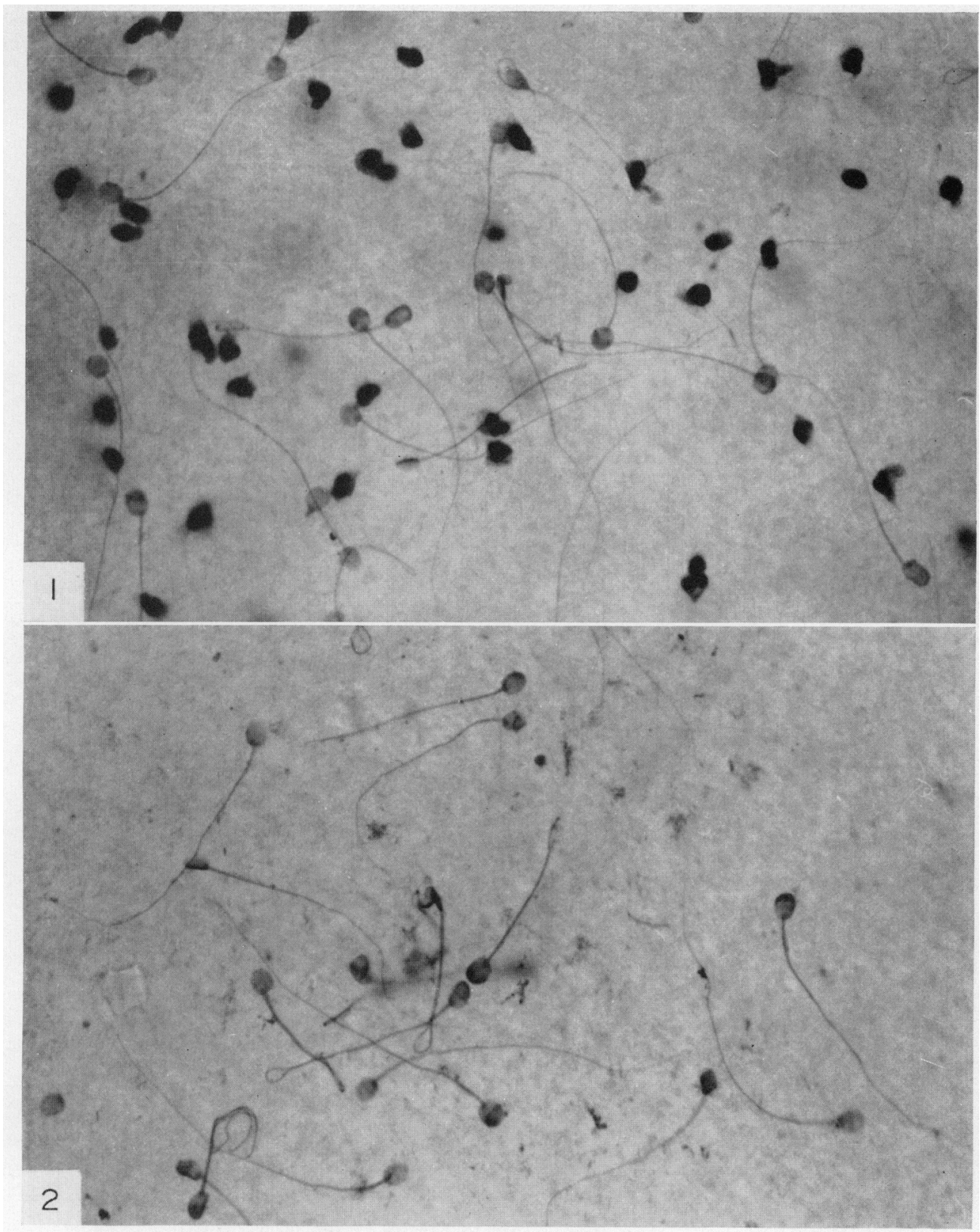

FIg. 1. Lower surface of chemotaxis filter showing migration of neutrophils towards guinea-pig spermatozoa incubated with heated serum $\left(30 \mathrm{~min}\right.$ at $56^{\circ} \mathrm{C}$ ) in Gey's solution. Hacmatoxylin, $\times 400$.

FIc. 2. Lower surface of chemotaxis filter showing absence of neutrophil migration towards guinca-pig spermatozoa incubated in Gey's solution alone. Hacmatoxylin, 400 . 


\section{DISCUSSION}

These results show that the strong chemotactic attraction exerted both by spermatozoa and by sperm-free seminal fluid is dependent on the presence in the incubation mixture of serum or plasma. In other words, spermatozoa and seminal fluid act as cytotaxigens but have little or no direct activity as cytotaxins. This cytotaxigenic activity could be mediated in one or more of the following ways: (a) through activation of complement; (b) through some system in serum or plasma other than complement; (c) through bacterial contamination of the test samples. Samples collected by ejaculation are likely to be contaminated with Gram-negative bacteria (Gunsalus, Salisbury \& Willett, 1941; Almquist, Prince \& Reid, 1949) and as little as $0.05 \mu \mathrm{g}$ bacterial endotoxin is known to be cytotaxigenic in the presence of serum (Meier \& Schär, 1957; Snyderman et al., 1968). These three possibilities are considered in turn in relation to both seminal fluid and spermatozoa.

\section{(1) Complement}

Seminal fluid fixes complement in the conventional haemolytic test and therefore probably generates at least part of its chemotactic activity by way of the complement system, liberating the active fragments described by other workers (Bokisch et al., 1969; Snyderman et al., 1969; Ward, Cochrane \& Müller-Eberhard, 1966). However, a considerable part of the chemotactic activity of seminal fluid is retained after the serum or plasma has been heatinactivated. This may be due either to a direct action of seminal fluid on one of the heat-stable complement components, by-passing the heat-labile $\mathrm{Cl}$ and $\mathrm{C} 2$, or to some other non-complement-dependent mechanism.

In contrast to seminal fluid, spermatozoa did not fix complement in a haemolytic test. On the other hand, it has been previously shown that animal spermatozoa fix complement in the presence of normal serum (Edwards, 1960) due to a reaction at the acrosome with a natural antibody of IgG type, which reacts with homologous and heterologous spermatozoa (Beck, Edwards \& Young, 1962; Johnson, 1968). The action of spermatozoa as cytotaxigens may, therefore, either be through complement fixation at levels too low to be detected in our haemolytic tests or it may be complement-independent. The high activity of heated serum and the lack of activity of heated plasma when incubated with spermatozoa are difficult to interpret. This result implies that some system other than the classical haemolytic complement cascade is playing a rôle and that products formed during blood coagulation may be important. Differences between plasma and serum when incubated with cytotaxigens have only previously been reported for chemotaxis of mononuclear phagocytes, using somatic cell extracts (Borel \& Sorkin, 1969; Borel, 1970).

\section{(2) Non-complement-dependent mechanisms}

The action of proteolytic enzymes on proteins other than complement may allow release of chemotactically-active split products from these proteins (Wilkinson, unpublished results). Seminal fluid contains many proteolytic enzymes and especially plasmin-like substances and fibrinolysins (Mann, 1964). We showed a heat-stable cytotaxigenic activity of seminal fluid in the presence 
of fibrin but, as the fibrin preparation used was crude, we cannot yet conclude that a fibrinolytic mechanism was responsible for this activity. Nevertheless, this observation on seminal fluid, coupled with the sharp differences in activity of spermatozoa in the presence of serum and of plasma discussed above, might imply that the coagulation and fibrinolytic systems, as well as complement, should be considered in interpreting the results obtained with both seminal fluid and with spermatozoa.

\section{(3) Bacterial contamination}

The possibility that the cytotaxigenic effect seen by us was mediated by bacterial products, especially endotoxin, is a real one. This effect of endotoxin is dependent on the presence of heat-labile complement components in serum or plasma (Keller \& Sorkin, 1967a; Snyderman et al., 1968). Gewurz, Pickering, Snyderman, Lichtenstein, Good \& Mergenhagen (1970) have suggested that bacterial endotoxin may consume complement and generate chemotactic factors by first combining with trace amounts of antibody in the serum, and it is possible that seminal fluid also acts in this way. However, we found that seminal fluid was still cytotaxigenic in the presence of serum or plasma which had been heat-inactivated. This activity must have been independent of endotoxin. Furthermore, epididymal guinea-pig spermatozoa obtained without bacterial contamination showed a similar activity to ejaculated, and therefore possibly contaminated, human spermatozoa.

We may, therefore, conclude that seminal fluid certainly acts through the complement system and possibly also through some other heat-stable system in serum and plasma. The activity of spermatozoa, on the other hand, is difficult to reconcile with a complement-mediated mechanism.

The foregoing observations in vitro must be considered in relation to the interaction in vivo of semen with the female genital secretions and its relation to the local leucocyte migration seen after mating or insemination. There is considerable evidence for the presence of complement components in the female reproductive tract. Thus Schumacher, Strauss \& Wied (1965) revealed the presence of $\beta_{1} \mathrm{C} / \beta_{1} \mathrm{~A}$ globulins in human cervical mucus between Days 15 and 28 of the menstrual cycle by reactions using specific antisera. Edwards, Talbert, Israelstam, Nino \& Johnson (1968) and Edwards, Johnson \& Rowson (1968) were also able to show $\beta_{1} \mathrm{C}$ globulin in human and bovine uterine secretions using diffusion chambers placed in the uterus. Furthermore, the presence of complement-fixing IgG in fluids of the female genital tract, of identical antibody specificity to that present in normal serum, was demonstrated by Symons \& Herbert (1971). It is also highly probable that the proteolytic and fibrinolytic enzymes of seminal fluid which, by analogy with radio-opaque fluid (Rowson, 1955), is rapidly transported as far as the Fallopian tubes, will react with proteins in the female genital secretions and that they may thus exert a complement-independent chemotactic effect. Furthermore, endotoxin-producing organisms introduced with the semen might be a further source of activity. Once leucocytes have invaded the uterine lumen, they may themselves act as a source of further chemotactic substances (Borel, Keller \& Sorkin, 1969) especially while they are actively phagocytic (Borel, 1970). 
The ovarian hormones influence mobilization of leucocytes in the tissues of the female reproductive tract; thus, in the mouse, there is an accumulation of leucocytes in the uterine wall at about the time of ovulation (Austin, 1957). However, unmated animals show little (Austin, 1957) or no (Reid, 1965) migration of leucocytes into the uterine lumen at this time. Migration of leucocytes into the lumen towards spermatozoa or other material, e.g. bacteria, is also dependent on the ovarian status. There is, in general, a slower rate of migration into the lumen in the luteal than in the oestrogen phase (reviewed by Haynes, 1967).

We would suggest that the migration of leucocytes into the lumen of the female genital tract after mating may be explained largely in terms of chemotactic attraction towards factors present in the semen. Our experiments have not, however, clarified which of several possible mechanisms is of greatest importance in causing this cell migration.

\section{ACKNOWLEDGMENTS}

E.S.M. was in receipt of financial assistance from the 'Schweizerische biologisch-medizinische Stipendienstiftung'. D.N.K.S. received a Student's Allowance from the Scottish Education Department. We are grateful for the excellent technical assistance of Miss Kathryn Brown and Mr J. Forrester. We also thank the Pathology Department, Western Infirmary, Glasgow, for making available the samples of human spermatozoa and seminal fluid.

\section{REFERENCES}

Almquist, J. Q., Prince, P. W. \& ReID, J. J. (1949) Bacteriological studies of bovine semen. I. Numbers of bacteria and the relation to fertility. F. Dairy Sci. 32, 543.

Austrn, G. R. (1957) Fate of spermatozoa in the uterus of the mouse and rat. F. Endocr. 14, 335.

Beck, J. S., Edwards, R. G. \& Young, M. R. (1962) Immune fluorescence technique and the isoantigenicity of mammalian spermatozoa. $\mathcal{F}$. Reprod. Fert. 4, 103.

Bokisch, V. A., Müller-Eberhard, H. J. \& Cochrane, G. G. (1969) Isolation of a fragment (C3a) of the third component of human complement containing anaphylatoxin and chemotactic activity and description of an anaphylatoxin inactivator of human serum. F. exp. Med. 129, 1109.

Borel, J. F. (1970) Studies on chemotaxis: effect of subcellular leukocyte fractions on neutrophils and macrophages. Int. Archs Allergy appl. Immun. 39, 247.

Borel, J. F., Keller, H. U. \& Sorkin, E. (1969) Studies on chemotaxis: effect on neutrophils of lysosomal and other subcellular fractions from leukocytes. Int. Archs Allergy appl. Immun. 35, 194.

Borel, J. F. \& Sorkin, E. (1969) Differences between plasma and serum mediated chemotaxis of leukocytes. Experientia, 25, 1333.

BOYDEN, S. (1962) The chemotactic effect of mixtures of antibody and antigen on polymorphonuclear leucocytes. F. $\exp$. Med. 115, 453.

Camprell, D. H., Garvey, J. S., Gremer, N. E. \& Sussdorf, D. H. (1964) Methods in immunology, p. 175. Benjamin, New York.

EDWARDS, R. G. (1960) Complement-fixing activity of normal rabbit serum with rabbit spermatozoa and seminal plasma. F. Reprod. Fert. 1, 268.

Edwards, R. G., Johnson, M. H. \& Rowson, L. E. A. (1968) Cited by Edwards, R. G. (1969) In: Immunology and Reproduction, p. 35. Ed. R. G. Edwards. International Planned Parenthood Federation, London.

Edwards, R. G., Talbert, L., Israelstam, D., Nino, H. V. \& Johnson, M. H. (1968) A diffusion chamber for exposing spermatozoa to human uterine secretions. Am. F. Obstet. Gynec. 102, 388.

Gewurz, H., Pigkering, R. J., Snyderman, R., Lightenstein, L. M., Good, R. A. \& Mergenhagen, S. E. (1970) Interactions of the complement system with endotoxic lipopolysaccharides in immunoglobulin-deficient sera. F. exp. Med. 131, 817. 
Gunsalus, I. C., Salisbury, G. W. \& Willetr, E. L. (1941) The bacteriology of bull semen. 7. Dairy Sci. 24, 911.

Hartman, C. G. (1928) Gestation in monkey (Macacus rhesus) and associated phenomena. Am. $\mathcal{F}$. Obstet. Gynec. 15, 534.

HAYNES, N. B. (1967) The infuence of the uterine environment on the phagocytosis of spermatozoa. In: Reproduction in the Female Mammal, pp. 500-512. Eds. G. E. Lamming and E. C. Amoroso. Butterworths, London.

HowE, G. R. \& BLAcK, D. L. (1963) Spermatozoon transport and leucocytic responses in the reproductive tract of calves. F. Reprod. Fert. 6, 305.

Johnson, M. H. (1968) The characterization of a natural antibody in normal guinea-pig serum reacting with homologous spermatozoa. F. Reprod. Fert. 16, 503.

Keller, H. U. \& Sorkin, E. (1967a) Studies on chemotaxis. V. On the chemotactic effect of bacteria. Int. Archs Allergy appl. Immun. 31, 505.

Keller, H. U. \& Sorkin, E. (1967b) Studies on chemotaxis. IX. Migration of rabbit leucocytes through filter membranes. Proc. Soc. exp. Biol. Med. 126, 677.

Keller, H. U. \& Sorkin, E. (1968) Chemotaxis of leucocytes. Experientia, 24, 641.

Mann, T. (1964) The biochemistry of semen and of the male reproductive tract, pp. 177-178. Methuen, London.

MaDonald, L. E., Black, W. G., McNutt, S. H. \& CAsida, L. E. (1952) The response of the rabbit uterus to instillation of semen at different phases of the estrus cycle. Am. F. vet. Res. 13,419.

MeIer, R. \& Schär, B. (1957) Vorkommen leukocytotaktischer Polysaccharide in bakteriellem, pflanzlichem und tierischem Ausgangsmaterial. Hoppe Seyler's Z. physiol. Chem. 307, 103.

Menge, A. G., Tyler, W. T. \& Casida, L. E. (1962) Factors affecting the removal of spermatozoa from the rabbit uterus. 7. Reprod. Fert. 3, 396.

Moyer, D. L., Rimpusit, S. \& Mishell, D. R. (1970) Sperm distribution and degradation in the human female reproductive tract. Obstet. Gynec., $\mathcal{N}$.Y. 35, 831.

Paul, J. (1959) Cell and tissue culture, p. 68. Livingstone, Edinburgh and London.

PitkJanen, I. G. (1960) The fate of spermatozoa in the uterus of the sow. zh. obshch. Biol. 21, 28 (Anim. Breed. Abstr. 28, 299).

ReID, B. L. (1965) The fate of uterine spermatozoa in the mouse post coitum. Aust. F. Zool. 13, 189.

Righardson, G. M. (1941) Preservation of liquid complement serum. Lancet, ii, 696.

Rowson, L. E. A. (1955) The movement of radio opaque material in the bovine uterine tract. $\mathrm{Br}$. vet. F. 111, 334.

Schumacher, G. F. B., Strauss, E. K. \& Wied, G. L. (1965) Serum proteins in cervical mucus. Am. J. Obstet. Gynec. 91, 1035.

Snyderman, R., Gewurz, H. \& Mergenhagen, S. E. (1968) Interactions of the complement system with endotoxic lipopolysaccharide. Generation of a factor chemotactic for polymorphonuclear leukocytes. F. exp. Med. 128, 259.

Snyderman, R., Shin, H. S., Phillips, J. K., Gewurz, H. \& Mergenhagen, S. E. (1969) A neutrophil chemotactic factor derived from $\mathrm{C5}$ upon interaction of guinea-pig serum with endotoxin. $\mathcal{F}$. Immunol. 103, 413.

Sorkin, E., Strecher, V. J. \& Borel, J. F. (1970) Chemotaxis of leucocytes and inflammation. Series Haematologica, (Munksgaard, Copenh.), 3, 131.

Symons, D. B. A. \& HeRBerT, J. (1971) Incidence of immunoglobulins in fluids of the rabbit genital tracts and the distribution of IgG-globulin in the tissues of the female tract. F. Reprod. Fert. 24, 55.

Ward, P. A., Cochrane, C. G. \& Müller-Eberhard, H. J. (1966) Further studies on the chemotactic factor of complement and its formation in vivo. Immunology, 11, 141.

Wilksnson, P. C. (1971) Chemotaxis of phagocytic cells towards proteins: the effect of protein denaturation. In: The Reticuloendothelial System and Immune Phenomena, p. 59. Ed. N. A. Di Luzio. Plenum Press, New York.

Yanagimachi, R. \& Chang, M. C. (1963) Infiltration of leucocytes into the uterine lumen of the golden hamster during the oestrous cycle and following mating. $\mathcal{F}$. Reprod. Fert. 5, 389. 